\title{
Developing motivation to become leaders amongst undergraduates in institutions of higher learning
}

\begin{abstract}
The management of academic and extracurricular programs to develop leadership skills amongst university students has become one of the top priorities in many universities since it is said that one of the core functions of universities is the development of future leaders (Astin \& Astin, 2000; Zimmerman-Oster \& Burkhardt,1999). While academic and extracurricular programs increasingly focus on the development of leadership awareness, character and skills, one of the missing links in the equation concerns the level of motivation to lead. This study reports on a study that involved 1860 undergraduate students in Malaysia in public and private institutions of higher learning (colleges and universities) on their motivation to lead, as well as university factors and personal factors affecting their level of motivation to lead. Based on the general findings of the study, literature review, and the authors' experiences in training student leadership, an integrated model of a student leadership development program is then proposed. This paper also makes several recommendations based on the research findings to managers of higher learning institutions (HEI) pertaining student leadership training and development programs.
\end{abstract}

Keyword: Motivation to Lead, Leadership Training, Student Leadership 